for expansion of cocoa production. $£ 156,973$ goes for soil conservation in Basutoland; a further $£ 81,394$ for control of tsetse fly in the Bechuanaland Protectorate; and $£ 234,000$ for development of broadcasting services in Kenya. Among the many grants for road development may be mentioned $£ 771,680$ to the Western Region of Nigeria ; $£ 288,000$ to Tanganyika (a further $£ 280,000$ for improvements to the Eastern Trunk Road) ; $£ 300,000$ for improvement of territorial roads in Kenya; $£ 156,000$ for survey of roads in Swaziland; $£ 817,250$ for construction of a trunk road from Scrian to Simanggang, Sarawak; and $£ 103,692$ for reconstruction of the East Coast Georgetown-Rosignol road, British Guiana. Grants of $£ 464,295$ to the Western Region, Nigeria, and $£ 99,000$ for the Scaries area, Sierra Leone, illustrate the grants for the development of water supplies. $£ 200,000$ is for the establishment of the Jamaica Institute of Technology, and among the many grants for university education can only be mentioned $£ 198,000$ for the erection of a Men's Hall of Residence at the University College of East Africa and a supplementary $£ 154,650$ for the erection of the new library ; $£ 200,000$ towards a new library at the University of Hong Kong; and $£ 156,188$ for the construction of buildings for the Faculty of Medicine, University College of the West Indies. There are numerous grants for secondary and primary education, the largest being $\$ 584,000$ for the expansion of general education in Lagos.

\title{
SAFETY IN MINES IN GREAT BRITAIN
}

$\mathrm{T}$ HE Mines Inspectorate, apart from the Headquarters organization at London, is divided into eight divisions, namely, Scottish, Northumberland and Cumberland, Durham, North Eastern, North Western, East Midland, West Midland and Southern, and South Western. Each division is in the charge of a divisional inspector who is required, under the Coal Mines Act of 1911, to present an annual report to the Minister of Power. The reports* for each of the eight divisions for 1956 have been published at intervals during the first few months of 1958; these are the last reports under the 1911 Act, for the Mines and Quarries Act, 1954, became effective on January 1, 1957.

The reports follow a similar pattern, beginning with an introduction which contains short accounts of production in the divisions, reorganization of collieries, new work, introduction of new methods of working, new machines used and experimental work on techniques of mining, roof support, shot firing, ventilation and so forth. This is followed by a section devoted to administration, in which are summarized the establishment and organization of the staff, the activities of the inspectors, inspections made on behalf of workmen, and prosecutions. One of the most interesting and significant features of this section in the reports is that nearly every divisional inspector refers to a serious shortage of staff, although one or two gave their opinion that there were signs of improvement in the near future. The shortage of inspectors has meant that the amount of preventive work undertaken was much less than desirable. The effect of the shortage was aggravated by the additional work caused in preparation for the implementation of the 1954 Act at the beginning of 1957 ; for example, in one division alone the Divisional Com. mittee of the Mining Qualifications Board (a committee which includes inspectors of mines) examined the qualifications of more than 2,000 mechanics and examined about 100 of these orally; and certificates were issued in that division for more than 500 deputies and for nearly 900 shot-firers. * Ministry of Power. Reports of H.M. Inspectors of Mines under
the Coal Mines Act 1911, for 1956. Durham Division. By W. Brown. the Coal Mines Act 1911, for 1956. Durham Division. By W. Brown. Pp. ii $+30+8$ plates. $2 s .6$. net. North Western Division. By G.
Hoyle. Pp. ii $+36+4$ plates. 3s. net. North Eastern Divisinn. By C. W. Scott. Pp. ii $+38+6$ plates. $2 s .6 d$. net. Scottish Division. By W. Widdas. Pp. ii $+28+4$ plates. 28. 6 d. net. East Midland Division. By W. B. Brown. Pp. ii $+34+4$ plates. 38. net. South Western Division. By T. A. Jones. Pp. ii $24+4$ plates. 28. $6 d$. net. West Midland and Southern Division. By J. E. Henshaw. Pp. ii $+24+$ 2 plates. $2 s$. $6 d$. net. Northumberland and Cumberland Division. By H. Hyde. Pp. ii $+30+6$ plates. 2s. 6 d. net. (London: H.M. Stationery Office, 1958.)
Over Great Britain as a whole, proceedings were taken against two management officials. Managements took legal proceedings against subordinate officials and workmen in about 340 cases, more than half of which were for contraventions in connexion with contraband (matches and smoking); two-thirds of these cases occurred in one division.

The main section of each report deals with accidents and their prevention. During the year there were 300 fatal accidents at mines (compared with an average of 396 in the three preceding years), and more than 1,760 men reportably injured (about 1,900 on the average in the three preceding years). There were also 148 dangerous occurrences (gas ignitions, fires, breakages of winding gear and so forth). Accidents are investigated and analysed by the inspectors. There is, considering the country as a whole, a gradual downward trend in the number of fatalities and reportable injuries each year, and in two divisions they were the lowest ever recorded; the numbers are, as the inspectors stress, unduly high. An analysis of all the accidents in 1956 shows that, in the opinion of the examining inspectors, about 80 per cent were avoidable (the actual percentages in different divisions vary from $76 \cdot 3$ to $81 \cdot 7$ ) and the remaining 20 per cent "unavoidable under existing conditions".

Of the avoidable accidents, some were due to defective machinery, some to neglect or breach of rules by officials or by workmen, but most (from about a half to three-quarters of avoidable accidents in different divisions) were classified as "avoidable by ordinary caution". Over Great Britain as a whole, about 35 per cent of the accidents were due to falls of ground, about 25 per cent were on haulage and transport, about 30 per cent due to miscellaneous causes, and about 10 per cent were due to accidents on the surface.

Sections in each of the reports are devoted to safety organization, training and education, and health and welfare. A noteworthy feature is the interest taken by miners in rescue training and rescue competitions, in first-aid work and competitions and in civil defence work. The rescue organization of the coal mining industry, which depends largely upon rescue teams of volunteers trained at special rescue stations, is a fine one and, as reported by the inspectors, whose duties include inspection of the rescue stations, there is no lack of volunteers for rescue work. 
The inspectors, as their reports show, take a keen interest in training and education, and report on the training centres, training faces and courses of instruction in each division. In 1956 more than 17,000 juveniles and more than 15,000 adults received preliminary training; these figures indicate the immense task of training in the coal industry, especially as face training has to be arranged and courses for potential shot-firers and potential deputies (quite apart from courses for senior officials, which are not referred to in detail).

Sections on health and welfare refer mainly to work carried out in improving dust control, ventilation, lighting, sanitation and so forth, and to the provision of medical centres at collieries.

Each divisional report includes a section devoted to horses. Although the number of horses employed at collieries is decreasing, more than 10,000 were employed in 1956. In general, the miner is devoted to his horses and they are well cared for.

Although the general pattern of the reports is similar, they are not stereotyped. Probably few people unconnected with the mining industry will read them, but they are very well worth reading, for they are personal reports and are far from the dry. as-dust documents they might have been.

The reports for 1957 of H.M. Inspectors of Mines and Quarries under the Mines and Quarries Act, 1954, have also recently been published; these are the first reports under the 1954 Act which became effective on January 1, 1957. It makes provision for all classes of mines and quarries to be dealt with together, and the Inspectors' reports include, in separate parts or sections, reports on coal mines; mines of stratified ironstone, shale and fireclay; miscellaneous mines (including metalliferous mines); and quarries*.

The general pattern is similar to the earlier divisional reports, which dealt only with coal mines and other so-called stratified mines. As may well have been expected, by far the greater part of each report deals with coal mines and the conclusions are similar to those for 1956.

Until 1957 the reports of H.M. Inspectors of Mines and Quarries on metalliferous mines and quarries were presented in a single publication for the whole country by H.M. Chief Inspector of Mines and Quarries under the Metalliferous Mines Regulation Act, 1872 , and the Quarries Act, 1894 ; the last report under these Acts was published early in 1958 and referred to the years $1954-56$. The new arrangement under the 1954 Act whereby H.M. Inspectors report annually on all mines and quarries in their division is more convenient in many ways than the former biennial reports.

The new reports show that particular attention is being paid at quarries to dust prevention and dust suppression and to encouragement in the use of protective clothing, especially safety hats, which many quarrymen seem loath to wear. S. G. WARD

* Reports of H.M. Inspectors of Mines and Quarries under the Mines and Quarries Act, 1954 , for 1957. Northumberland and Cumberland Division. By H. Hyde. Pp. iv $+41+6$ plates. $3 s$. 6d. net. Scottish Division. By W. Widdas. $P p$ iv $+41+6$ plates. 48 . net North Western Division. By G. Hoyle. Pp. $11+42+6$ plates. 3s. Gid. net. Durham Division. By W. Brown. Pp. iv +23. 2s. 6d. net. South Western Division. By T. A. Jones. Pp. iv $+28+4$ plates. $2 s .6 d$. net. West Midland and Southern Division. By J. E. Henshaw
Pp. iv $+34+2$ plates. $3 s$. net. North Eastern Division. By C. W Pp. iv $+34+2$ plates. $3 s$. net. North Eastern Division. By C. W Scott. Pp. ii $+44+7$ plates. $3 s$. 6d. net. East Midland Division.
By W. B. Brown. Pp. ii $+38+7$ plates. $38.6 d$. net. (London: $H . M$. Station ry Office, 1958.)

\section{PRESSURE WELDING OF METALS}

W ELDING engineering is a profession now well established in industry and is supported by a research association and a technical institute. In Britain (unlike the United States and the U.S.S.R.) it has not achieved independent status at any university, and it is therefore practised by metal. lurgists and mechanical, electrical and civil engineers, in whose training it has occupied a very subsidiary role. However, as a result of the division of metallurgy into physical and industrial aspects at the University of Birmingham, research into and the teaching of the basis of metallic jointing practice now figures prominently in the Department of Industrial Metallurgy. To supplement the academic work, occasional conferences are organized to promote the exchange of information and ideas with other workers in the field. The second of these conferences, on the pressure welding of metals, was held on June 19, under the chairmanship of Prof. E. C. Rollason, head of the Department of Industrial Metallurgy, and was attended by ninety representatives of industry, the research associations and the universities.

After explaining the purpose of these conferences, Prof. Rollason reviewed the origins and development of the practice of pressure welding and the progress that had been made towards establishing a theoretical model. Three papers were then presented, the first by Mr. J. A. Donelan (Research Laboratories, General Electric Co.) dealt with industrial practice, the second by Messrs. L. R. Vaidyanath, M. G. Nicholas and D. R. Milner gave an account of the researches being carried out at the University of Birmingham, and the third paper by Dr. E. Holmes (University of Nottingham) was concerned with the relative importance of movement at the interface, oxide break. up, and the deformation of surface asperities upon bond formation.

The idea of joining metals by pressure is not new, as it has been employed in the hammer-forged blacksmith's weld from the earliest days of the use of iron; this, however, is a special case in that it depends on the squeezing out of a molten layer of slag between the two components to be joined. The general practice of pressure welding metals, without melting, was established in 1887 with resistance heating used to aid the deformation of the interface; then, during the Second World War, the cold welding process was developed in which metals are joined at room temperature. The majority of metals can now be pressure welded, if not at room temperature, then at higher temperatures. The advantages of the process are that the joint possesses none of the weaknesses inherent in the cast structure associated with the more normal welding techniques, and it is the only metallic jointing process that can be carried out at room temperature, and is therefore particularly suitable to the canning of delicate components such as detonators or transistors. One of the widest applications of pressure welding is to the production of ply metals by rolling, so that the advantages of the properties of two or more metals or alloys can 